\title{
Selecting Appropriate Bedding to Reduce Locomotion Problems in Broilers
}

Author(s)
Almeida Paz ICL1
Garcia RG ${ }^{1}$
Bernardi $\mathrm{R}^{2}$
Nääs IA 1
Caldara FR 1
Freitas LW³
Seno LO1
Ferreira VMOS²
Pereira DF
Cavichiolo F1
1 Professor at Faculdade de Ciências Agrária
da Universidade Federal da Grande
Dourados, Dourados, MS.
2 MSc student - Curso de Pós-Graduação em
Zootecnia da Universidade Federal da
Grande Dourados.
3 Undergraduate student - Curso de
Zootecnia da Faculdade de Ciências Agrária
da Universidade Federal da Grande
Dourados.
Professor - Universidade Estadual Paulista,
Campus Experimental de Tupã, Tupã, SP.

\section{Mail Address}

\section{ICL Almeida Paz}

Professor

Faculdade de Ciências Agrária

Universidade Federal da Grande Dourados

Dourados, MS, Brasil.

E-mail: ibiarapaz@ufgd.edu.br
Gait score, leg problems, multicriteria analysis, rice husks, wood shaving.

\section{ABSTRACT}

Two experiments were carried out at the Poultry Sector of the School of Agrarian Sciences of the Federal University of Grande Dourados to evaluate the incidence of leg problems in broilers reared on two distinct types of bedding material: rice husks or wood shavings, both new and reused. In both trials, a randomized experimental design was applied in factorial arrangement $(2 \times 2 \times 2)$ using two genetic strains (Cobb ${ }^{\circledR}$ or Ross $^{\circledR}$ ); two sexes (male or female), and two litter materials (rice husks or wood shavings). In each trial 1080 one day pullets were reared equally divided in the treatments. The birds were placed in $4.5 \mathrm{~m}^{2}$ boxes at a density of 10 birds $\mathrm{m}^{-2}$. All birds were fed diets with equal nutritional density, and water was offered ad libitum. Feeds were divided in three phases: starter diet (1 - 21 days), grower diet (22 - 35 days), and finisher diet (36 - 45 days). On day 45, fifty birds were randomly selected in each experiment to evaluate flock leg problems. The following parameters were analyzed: gait score, incidence of valgus and varus disorder, footpad dermatitis, femoral degeneration, tibial dyschondroplasia, and spondylolisthesis. Ambient temperature during rearing and litter caking and moisture content were recorded in four boxes per treatment. The analytical hierarchy process was used to organize the data into specific criteria. Several criteria, related to the attributes that were determinant according to the statistical analysis, were chosen in order to provide the best input to the process. Results indicated that new wood-shavings bedding was the most appropriate bedding to prevent locomotion problems, followed by new rice husks, reused wood shavings, and reused rice husks. However, when leg problems were associated to sex and genetic strain, male Ross birds strain presented less problems when reared on new rice husks, followed by new wood shavings

\section{INTRODUCTION}

Pathologies of the broiler locomotion system are reported to be related to inadequate nutrition (Bilgili et al., 2006; Cook, 2000; Murakami, 2000), stressful rearing environment (Cordeiro et al., 2009; Dawkins 2003), genetic strain (Bokkers \& Koene, 2004; Bizeray et al., 2000; Gonzáles \& Macari, 2000; Julian, 2005), and low litter quality (Oliveira \& Carvalho, 2002; Shields et al., 2004). When reared in suboptimal conditions, broilers may show respiratory problems and present lack in flock uniformity and carcass quality (Bilgili et al., 2009).

Locomotion problems are generally associated with the factors mentioned above and may cause economic losses from 10 to $40 \%$ in broiler production due to carcass condemnation and downgrading at processing (Almeida Paz, 2008; Bains et al., 1998, Murakami, 2000). The most common leg disorders, such as femoral lesions, tibial 
Almeida Paz ICL, Garcia RG, Bernardi R, Nääs IA, Caldara FR, Freitas LW, Seno LO, Ferreira VMOS, Pereira DF, Cavichiolo F
Selecting Appropriate Bedding to Reduce Locomotion Problems in Broilers dyschondroplasia, and spondylolisthesis, among other pathologies, are considered important welfare issues as they prevent birds from reaching feed and water (Weeks et al., 2000). It is also reported in current literature that litter quality may play an important role in leg pathology results as it is related to an increase in activity levels when broilers are encouraged to display normal behaviors that require energetic movement, which includes exercise of the legs, such as walking, foraging, and dust bathing (Arnould et al., 2004; Shields et al., 2005).

Several attempts of replacing the traditional litter material have been made, particularly to increase the sustainability of the poultry industry (Chamblee \& Yeatman, 2003; Dias et al., 1987; Grimes et al., 2002; Grimes et al., 2007; Santos et al., 2000). Factors that influence the efficiency of a determined litter type are particle size, moisture content and buildup, caking rate, and other physical characteristics of the material (Hernandes et al., 2002; Oliveira \& Carvalho, 2002; Toghyani et al., 2010). The selection of the appropriate litter material in broiler production has several inputs, and it may be determined by specific characteristics to achieve the desired final results.

The objective of this research study was to select the most appropriate broiler litter material by the use of multicriteria analytical hierarchy process (AHP) aiming at reducing locomotion problems.

\section{MATERIALS AND METHODS}

\section{Birds, housing and management}

A total of 2160 day-old Cobb $^{\circledR}(270$ males $=$ GS1M and 270 females $=$ GS1F) and Ross $^{\circledR}$ (270 males $=$ GS2M and 270 females $=$ GS2F) broiler chicks were obtained from a commercial hatchery and reared in pens $\left(4.5 \mathrm{~m}^{2}\right)$ with wood shaving or rice husks bedding. The applied flock density was 10 birds $\mathrm{m}^{-2}$. The trial was carried out at the experimental broiler house $50 \mathrm{~m}$ long $\times 10 \mathrm{~m}$ wide $\times 3 \mathrm{~m}$ high), equipped with fans and sprinkling system to control heat stress, at the Poultry Sector of the School of Agrarian Sciences of the Federal University of Grande Dourados.

All birds received feed and water ad libitum during the entire experimental period. Feed was divided into three phases: starter diet (1 - 21 days), grower diet (22 - 35 days), and finisher diet (36 - 45 days).

\section{Experimental design}

Two experiments were carried out as follows (Table 1):

- Experiment I - two different types of bedding, rice husks or wood shavings were tested; and

- Experiment II - the litters used in experiment I were treated by fermentation using a plastic canvas to cover the material.

During both trials, birds were submitted to the same management and feeding practices; only litter was changed.

A randomized experimental design was applied using a factorial arrangement that consisted of was a random factorial composed by two genetic strains, two sexes, and two litter materials $(2 \times 2 \times 2)$, with a total of 16 treatments of two replicates per treatment, using 48 pens.

\section{Locomotion evaluation}

In this evaluation, 20 birds per treatment were randomly selected and the following parameters were observed at 45 days of age: gait score, incidence of valgus and varus deformity, footpad dermatitis/lesion, femoral degenerative joint lesion, tibial dyschondroplasia, and spondylolisthesis. After the gait score observation, birds were euthanized by cervical dislocation, and further analyses were carried out at the Meat Laboratory of the School of Agrarian Sciences of the Federal University of Grande Dourados.

\section{Gait score}

Visual observation of gait score was performed in 45-d-old broilers randomly selected from the treatments. Gait score was estimated using a threescore scale system (Nääs et al., 2009), by a skilled observer.

\section{Joint deviation}

This was observed in the poultry house during rearing immediately after gait score evaluation. It consisted in measuring the angle between the leg joints using a caliper rule and a protractor. The varus

\begin{tabular}{|c|c|c|c|c|c|c|c|}
\hline \multicolumn{4}{|c|}{ Experiment I } & \multicolumn{4}{|c|}{ Experiment II } \\
\hline \multicolumn{2}{|c|}{ GS1 } & \multicolumn{2}{|c|}{ GS2 } & \multicolumn{2}{|c|}{ GS1 } & \multicolumn{2}{|c|}{ GS2 } \\
\hline Male & Female & Male & Female & Male & Female & Male & Female \\
\hline Wood shavings & Wood shavings & Wood shavings & Wood shavings & Wood shavings & Wood shavings & Wood shavings & Wood shavings \\
\hline Rice husks & Rice husks & Rice husks & Rice husks & Rice husks & Rice husks & Rice husks & Rice husks \\
\hline
\end{tabular}




\begin{abstract}
Almeida Paz ICL, Garcia RG, Bernardi R, Nääs IA, Caldara FR, Freitas LW, Seno LO, Ferreira VMOS, Pereira DF, Cavichiolo F
\end{abstract}

Selecting Appropriate Bedding to Reduce Locomotion Problems in Broilers deformity was characterized when the angle between the tibia and the third finger was negative, whereas the valgus deformity was characterized when the angle was positive.

\section{Footpad dermatitis}

This evaluation was made by observing the condition of the footpad of both feet. When a lesion was found, its diameter was measured using a mmscale rule, and scored according to a 0-2 scale, as follows: score 0 corresponded to a healthy footpad; 1 was equivalent to lesions with diameter up to $5 \mathrm{~mm}$; and 2 to lesions with diameter larger than $5 \mathrm{~mm}$.

\section{Femoral degenerative joint lesion}

The left and right heads of the femur were submitted to gross examination and scored according to a 0-2 scale. A healthy femur corresponded to $0 ; a$ femur with the initial lesions was scored 1 , and severe lesion corresponded to score 2 (Garner et al., 2002; Almeida Paz, 2008).

\section{Tibial dyschondroplasia}

Tibial dyschondroplasia was evaluated by gross examination of both legs and scored according to growth cartilage thickness using a 0-2 scale. Score 0 was given for healthy bones; score 1 was given when there was an initial lesion between 1-3mm; and score 2 was given when the cartilage was thicker than $3 \mathrm{~mm}$ (Almeida Paz et al., 2005).

\section{Evaluation of spondylolisthesis}

This parameter was evaluated by analyzing the integrity of the vertebral column. The vertebral column was longitudinally and medially cut, and classified as presenting disorders or not (Paixão et al., 2007).

\section{Litter characteristics}

Litter $\mathrm{pH}$ was determined using a $0.01 \mathrm{~kg}$ litter sample diluted by agitation in deionized water $(1: 2.5)$. and left for 1 hour for resting, after which $\mathrm{pH}$ was read using aa digital pHmeter (Oliveira et al., 1988). Litter moisture content was obtained by calculating the weight difference of a sample before and after drying at $65^{\circ} \mathrm{C}$ for 72 hours (Medeiros et al., 2008). The degree of caking was measured in three places at each pen using a soil hydraulic analogical penetrograph, which measured the resistance of the bedding surface.

\section{Statistical analysis}

The data collected on locomotion problems were submitted to analysis of variance at $95 \%$ significance level using the Wilcoxon test for the non-parametric data. Litter data were also submitted to the analysis of variance at $95 \%$ significance level and the means were compared using Tukey's test.

\section{Analytic Hierarchy Process (AHP)}

The analytic hierarchy process (AHP) is characterized by the possibility of analyzing a multicriteria problem and to propose a decision. Criteria hierarchy levels are chosen based on qualitative and quantitative characteristics. AHP technique is widely used both in individual and group decision making environments. Bolloju (2001) evaluated the application of AHP to solve a specific category of decision problems that involves different decision-makers solving similar questions independently. Using the consensus approach, the comparison in this present study was made following the mathematic procedure: let aij denote the comparison of element $i$ to element $j$ in pair-wise comparison matrix $A$, and suppose there are $\mathrm{n}$ alternatives. In the first approach, the group of decision-makers is required to reach a consensus on each entry aij in $\mathrm{A}$. Let aij $k$ denote the comparison of element $i$ to element $j$ for decision-maker $k(k=1,2, \ldots, n)$ in pair-wise comparison matrix $A$.

The individual judgments of the $n$ decision-makers are combined using the geometric mean to produce the entry:

$$
\text { aij=[aij' } \left.\times a i^{2} \times \cdots \times a i^{2}\right]^{1 / n} \quad \text { Eq.1 (Bolloju, 2001). }
$$

If weight $w^{k}$ is assigned to the decision-maker $k$, then the weighted arithmetic mean has also been used to combine the judgments of decision-makers.

a $i j=w^{1} a i^{1}+w^{2} a i j^{2}+\cdots+w n a i j^{n}$ Eq. 2 (Bolloju, 2001)

Criteria pair-wise were compared according to their possibilities of reaching the proposed goal (Saaty, 1980; Saaty, 1998). The multicriteria comparison was used to select the most appropriate litter to reduce broiler locomotion problems. Several criteria related to the attributes that were considered determinant by the statistical analysis were chosen to provide the best inputs to the process (Figure 1). Weights were given to the criteria based on the experimental results to provide a hierarchy matrix $A$. The online software AHPProject (2009) was used for the pair-wise calculations. 
Almeida Paz ICL, Garcia RG, Bernardi R, Nääs IA, Caldara FR, Freitas LW, Seno LO, Ferreira VMOS, Pereira DF, Cavichiolo F

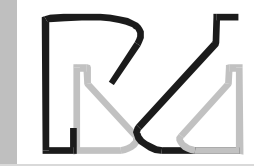

Selecting Appropriate Bedding to Reduce Locomotion Problems in Broilers

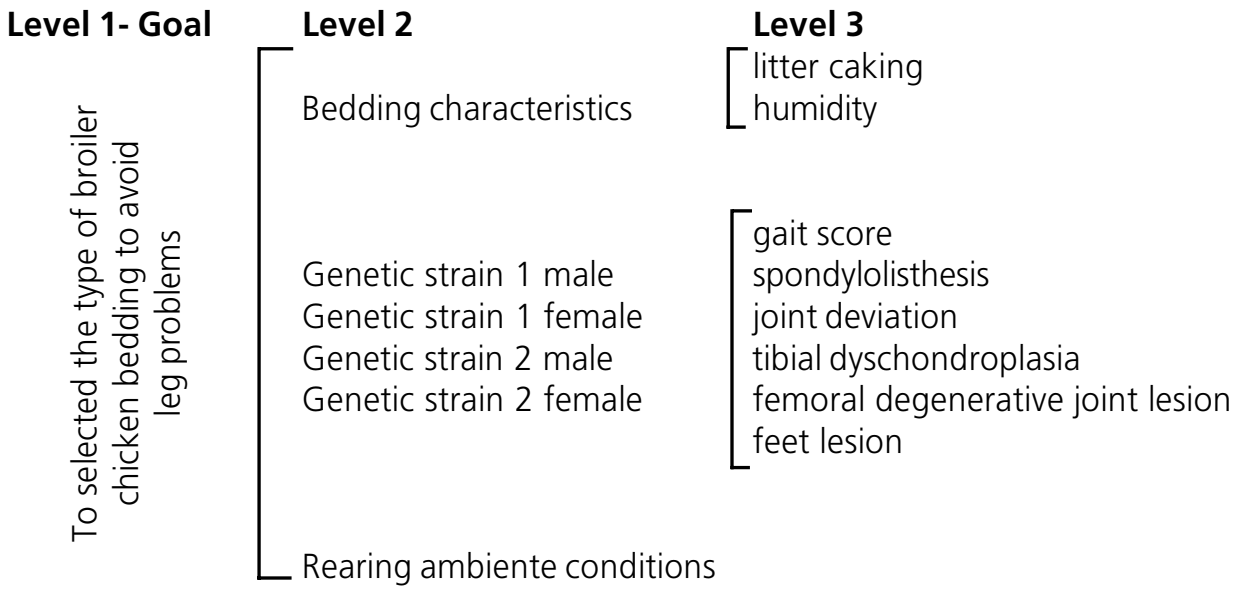

Figure 1 - Diagram of the criteria used for the selection of the most appropriate bedding material for broilers aiming at reducing locomotion problems. that wood shavings promote less caking and retain less humidity (Martland, 1984).

\section{Selection of litter with the aim of reducing locomotion problems}

The results of the pair-wise comparison of the alternatives generated by the data are shown in Figures 3 and 4 . Four alternatives were found, and each was appropriate for a specific genetic strain and sex. New rice-husks litter was the best choice for GS2M, while new wood-shavings litter was the best litter material choice for all

\section{RESULTS AND DISCUSSION}

The main objectives of litter are to provide some thermal comfort to the birds, preventing excessive floor moisture by absorbing liquid from the excreta. It is also expected to produce a minimum of noxious gases and dust by supplying acceptable rearing conditions to the broilers (Hernandes et al., 2002).

\section{Overallbedding selection}

Applying the pair-wise comparison using the criteria shown in Figure 1 and the results from the statistical analysis, the overall best litter material was found as seen in Figure 2. New wood shavings (33\%) was the best choice, followed by the new rice husks (27.7\%), reused wood shavings (20.6\%), and reused rice husks $(18.7 \%)$. The property related to litter caking and humidity content was the most determinant second level criterion (11.6\%). Genetic strain and sex also influenced bedding alternatives, and will be discussed later. Rearing ambient conditions were the same for all alternatives.

Wood shavings have been widely used for poultry bedding (broiler, turkey, duck and layers) worldwide for its good moisture absorption capacity, in addition to its availability (Angelo et al., 1997; Sorbara et al., 2000). Rice husks have been studied and pointed as an appropriate alternative litter material (Bilgili et al., 2009; Chamblee \& Yeatman, 2003). Rice husks are rapidly gaining space in the broiler litter market. Their size, freedom from dust, density, thermal conductivity, drying rate, and compressibility make them an ideal litter material.

When reused, wood shavings presented the best litter caking and humidity values, equivalent to $4.4 \%$, while the reused rice husks presented $2.7 \%$, indicating other alternatives (Figure 3a). When testing both reused litter substrates, reused rice husks were the best choice for GS2M (Figure 3b), while in the other tested treatments, reused wood shavings presented better performance. When comparing new rice husks with reused wood shavings (Figure 4a), new rice-husks litter was the best choice for all tested broilers, except for GS2F. When new rice husks were compared with reused rice husks (Figure 4b), new rice-husks was the best material for all tested strains and sexes.

Wood shavings seems to be a good alternative litter material choice for most broilers tested in this experiment; however, for GS2M birds, rice husks were much better for the prevention of locomotion problems. Similar results were found by Toghyani et al. (2010) in a study on the behavioral activities on distinct types of litter substrate using GS2. Although the birds had spent $19 \%$ of their time in the wood shavings and $13 \%$ in the rice husks, the activity of walking was greater on the rice husks.

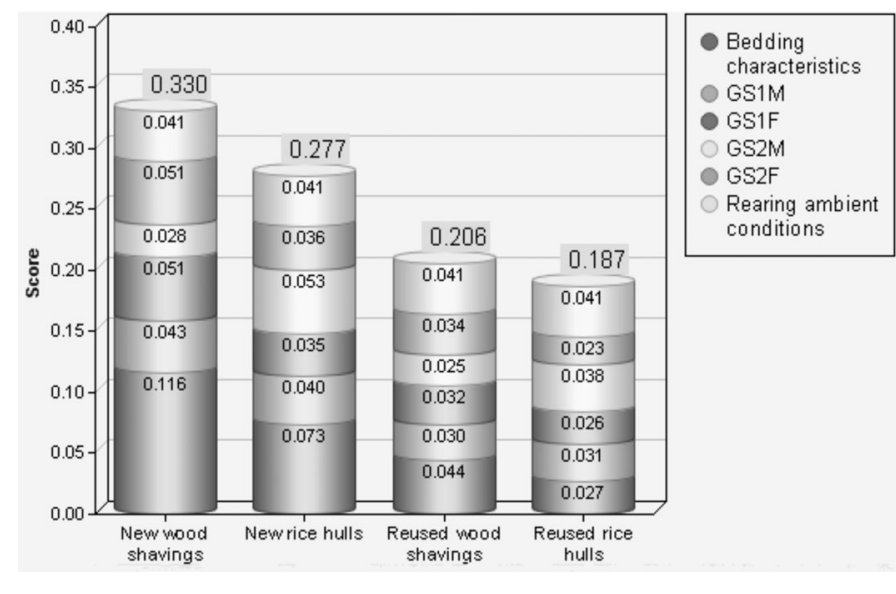

Figure 2 - Overall AHP score results of the bedding alternatives aiming at reducing locomotion problems. 
Almeida Paz ICL, Garcia RG, Bernardi R, Nääs IA, Caldara FR, Freitas LW, Seno LO, Ferreira VMOS, Pereira DF, Cavichiolo F
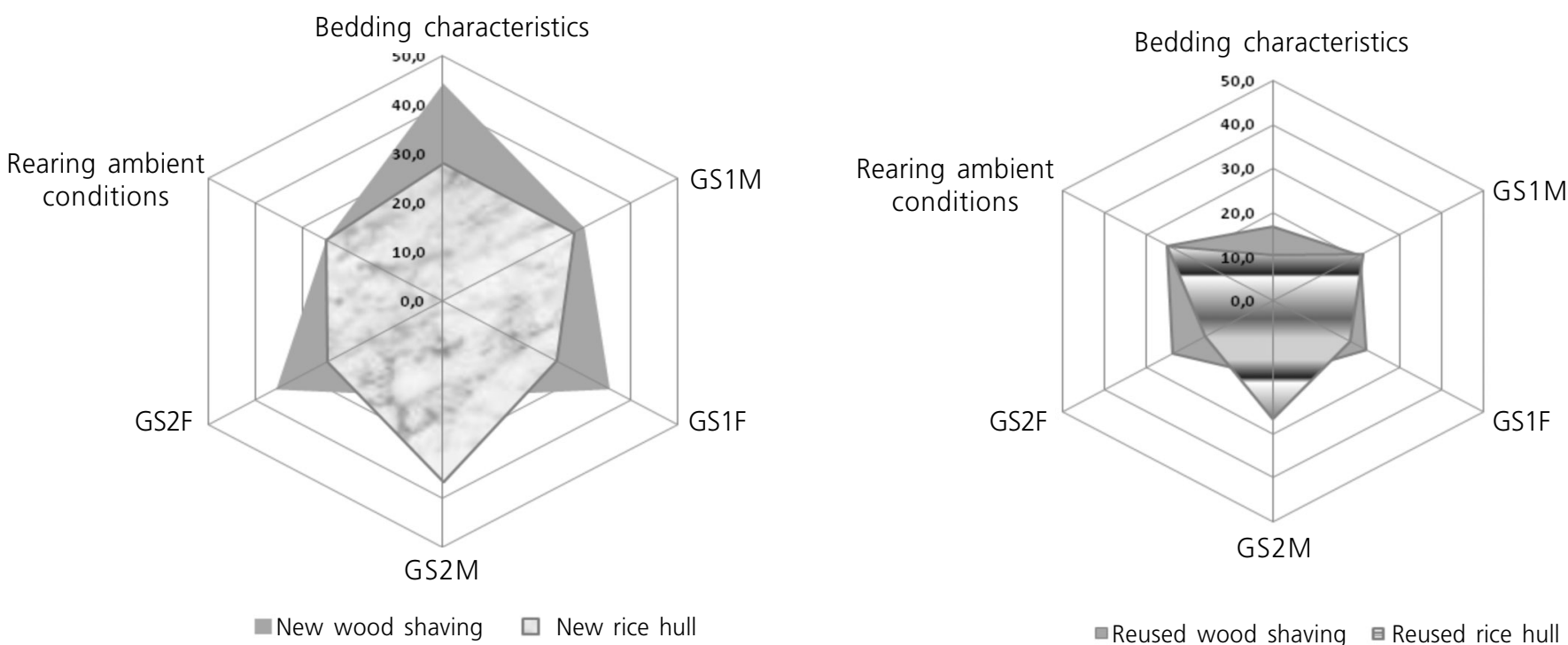

New wood shaving

$\square$ Reused wood shaving a Reused rice hull

Figure 3 - Comparison of the tested new (a) and reused (b) litter materials - wood shavings or rice husks - considering the obtained reduction (\%) of locomotion problems.
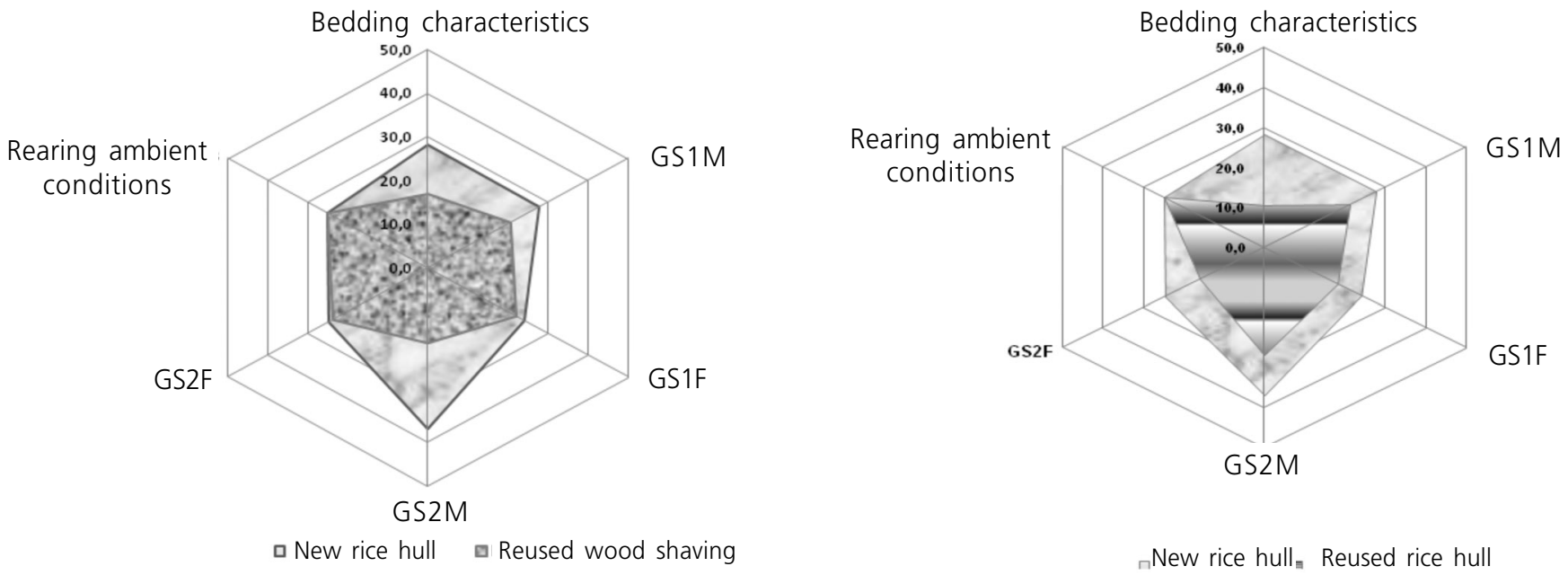

${ }_{\curvearrowleft}$ New rice hull

Figure 4 - Comparison of the tested new rice husks and reused wood shavings (a) and new rice husks and reused rice husks (b) as litter material aiming at reducing (\%) locomotion problems.

Several researches in assessing welfare were done for comparing broiler chicken behavioral expression reared on distinct bedding materials (Arnould et al., 2004; Chamblee \& Yeatman, 2003; Shields et al., 2004; Shields et al., 2005; Stub \& Vestergaard, 2001) and apparently their preference for expressing natural behavior such as stretching and preening is on sand bedding; however, their second choice appears to be soft wood shavings, followed by rice husks.

In this present study, the selection criteria were established taking into consideration the lower incidence of leg disorders that occurred in the trials, and applying the corresponding weight to the choices related to the best results in favor of the chickens.

\section{CONCLUSIONS}

New wood shavings were the evaluated litter material that led to less locomotion problems in both studied genetic strains during rearing, followed by new rice husks, reused wood shavings and reused rice husks. However, when leg problems were associated with sex, male Ross broilers (GS2M) presented a slightly lower incidence of locomotion problems when reared on new rice-husks litter, followed by new woodshavings litter. 


\author{
Almeida Paz ICL, Garcia RG, \\ Bernardi R, Nääs IA, Caldara FR, \\ Freitas LW, Seno LO, Ferreira \\ VMOS, Pereira DF, Cavichiolo F
}

Selecting Appropriate Bedding to Reduce Locomotion Problems in Broilers

\section{REFERENCES}

AHPProject [cited 2010 may 6]. Available from: http// :www.ahpproject.com.

Almeida Paz ICL, Mendes AA, Takita TS, Vulcano LC, Guerra PC, Wechsler FS. et al. Comparison of techniques for tibial dyschondroplasia assessment in broiler chickens. Revista Brasileira de Ciência Avícola 2005; 7(1):27-31.

Almeida Paz ICL. Problemas locomotores e técnicas de mensuração. Anais da Conferência FACTA 2008 de Ciência e Tecnologia Avícolas; 2008; Santos, SP. Brasil. p. 128-137.

Angelo JC, Gonzales E, Kongo N. Material de cama: qualidade, quantidade e efeito sobre o desempenho de frango de corte. Revista Brasileira de Zootecnia 1997; 26(1):121-130.

Arnould C, Bizeray D, Faure JM, Leterrier C. Effects of the addition of sand and string to pens on use of space, activity, tarsal angulations and bone composition of broiler chickens. Animal Welfare 2004; 13:87-94.

Bains BS, Brake JT, Pardue SL. Reducing leg weakness in commercial broilers. World Poultry Science Journal 1998; 14(1):24-27.

Bilgili SF, Alley MA, Hess JB, Nagaraj M. Influence of age and sex on footpad quality and yield in broiler chickens reared on low and high density diets. Journal of Applied Poultry Research 2006; 15:531-537.

Bilgili SF, Alley MA, Hess JB, Blake JP, Macklin KS, Sibley JL. Influence of bedding material on footpad dermatitis in broiler chickens. Journal of Applied Poultry Research 2009; 18:583-589.

Bizeray D, Laterrier C, Constantin P, Picard M, Faure JM. Early locomotor behaviour in genetic stocks of chickens with different growth rates. Applied Animal Behaviour Science 2000; 68:231-242.

Bokkers EAM, Koene P. Motivation and ability to walk for a food reward in fast and slow- growing broilers to 12 weeks of age. Behavioural Processes 2004; 67:121-130.

Bolloju N. Aggregation of analytic hierarchy process models based on similarities in decision makers' preferences. European Journal of Operational Research 2001; 128(3):499-508.

Chamblee TN, Yeatman JB. Evaluation of rice hull ash as broiler litter. Journal of Applied Poultry Research 2003; 12:424-427.

Cook ME. Skeletal deformities and their causes: introduction. Poultry Science 2000; 79:982-984.

Cordeiro AFS, Naas IA, Salgado DD. Field evaluation of broiler gait score using different sampling methods. Revista Brasileira de Ciencia Avicola 2009; 11(3):149-154.

Dawkins MS. Behavior as a tool in the assessment of animal welfare. Zoology 2003; 106(4):383-7.

Dias PGO, Curvelo FA, Monteiro, JML. Efeito de diferentes tipos de cama sobre o desempenho de frangos de corte. Anais da $24^{a}$ Reunião
Anual da Sociedade Brasileira de Zootecnia; 1987; Brasília, DF. Brasil: SBZ; 1987. p.367.

Garner JP, Falcone C, Wakenell P, Martin M, Mench JA. Reliability and validity of a modified gait scoring system and its use in assessing tibial dyschondroplasia in broilers. British Poultry Science 2002; 43(3):355-363.

Gonzales E, Macari M. Enfermidades metabólicas em frangos de corte. In: Berchieri Júnior A; Macari M. Doenças das aves. Campinas: FACTA; 2000. p.449-464.

Gonzales E, Mendoça Jr. CX. Problemas locomotores em frangos de corte. Anais do $7^{\circ}$ Simpósio Brasil Sul de Avicultura; 2006; Chapecó, SC. Brasil. p.79-94.

Grimes JL, Smith J, Williams CM. Some alternative litter materials used for growing broilers and turkeys. World's Poultry Science Journal 2002; 58:515-525.

Grimes JL, Carter TA, Gernat AE, Godwin JL. A novel bedding material made from cotton waste, gypsum, and old newsprint for rearing turkeys. Journal of Applied Poultry Research 2007; 16:598-604.

Julian R. Patologias ósseas em aves. Anais da Conferência Apinco 2005 de Ciência e Tecnologia Avícolas; 2007; Campinas, SP. Brasil: FACTA; 2005. v.1. p.107-122.

Martland MF. Wet litter as a cause of plantar pododermatitis leading to foot ulceration and lameness in fattening turkeys. Avian Pathology 1984; 13:241-252.

Medeiros R, Santos BJM, Freitas M, Silva OA, Alves FF, Ferreira E. A adição de diferentes produtos químicos e o efeito da umidade na volatilização de amônia em cama de frango. Ciência Rural 2008; 38(8):2321-2326

Murakami A. Balanço eletrolítico da dieta e sua influência sobre o desenvolvimento dos ossos de frangos. Anais da Conferência Apinco 2000 de Ciência e Tecnologia Avícolas; 2000; Campinas, SP. Brasil: FACTA; 2000. v.2, p.33-56.

Nääs IA, Almeida Paz ICL, Baracho MS, Menezes AG, Bueno LGF, Almeida ICL, Moura DJ. Impact of lameness on broiler well-being. Journal of Applied Poultry Research 2009; 18:432-439.

Oliveira MC, Carvalho ID. Rendimento e lesões em carcaças de frangos de corte criados em diferentes camas e densidades populacionais. Ciência e Agrotecnologia 2002; 26(5):1076-1081.

Oliveira MDS, Vieira PF, Sampaio AAM. Efeito do tempo de estocagem sobre a composição bromatológica da cama de frango. Revista Brasileira de Zootecnia 1988; 17(2):115-119.

Paixão TA, Ribeiro BRC, Hoerr FJ, Santos RL. Espondilolistese em frango de corte no Brasil. Arquivo Brasileiro de Medicina Veterinária e Zootecnia 2007; 59(2):523-526.

Saaty TL. The analytic hierarchy process. New York: McGraw-Hill; 1980.

Saaty TL, Vargas LG. Diagnosis with dependent symptoms: Bayes 


\begin{abstract}
Almeida Paz ICL, Garcia RG, Bernardi R, Nääs IA, Caldara FR, Freitas LW, Seno LO, Ferreira VMOS, Pereira DF, Cavichiolo F
\end{abstract}

Theorem and the analytic hierarchy process. Operations Research 1998; 46:491-502.

Santos EC, Cotta JTB, Muniz JA, Fonseca RA, Torres DM. Avaliação de alguns materiais usados como cama sobre o desempenho de frangos de corte. Ciência Agrotécnica 2000; 14(4):1024-1030.

SAS Institute. User's Guide. Cary, NC; 1996.

Shields SJ, Garner JP, Mench JA. Dustbathing by broiler chickens: a comparison of preference for four different substrates. Applied Animal Behaviour Science 2004; 87:69-82.

Shields SJ, Garner JP, Mench JA. Effect of sand and wood-shavings bedding on the behavior of broiler chickens. Poultry Science 2005; 84:1816-1824.

Sorbara J, Rizzo MS, Laurentiz AC, Iturrino RP, Berchielli TT, Moraes VMB. Avaliação da polpa de citros peletizada como material para cama de frangos de corte. Revista Brasileira de Ciência Avícola 2000; 2(3):273-280

Stub C, Vestergaard KS. Influence of zinc bacitracin, light regimen and dustbathing on the health and welfare of broiler chickens. British Poultry Science 2001; 42(5):564-568.

Toghyani M, Gheisari A, Modaresi M, Tabeidian SA, Mehdi Toghyani M. Effect of different litter material on performance and behavior of broiler chickens. Applied Animal Behaviour Science 2010; 122:48-52.

Weeks CA, Danbury TD, Davies HC, Hunt P, Kestin SC. The behaviour of broiler chickens and its modification by lameness. Applied Animal Behaviour Science 2000; 67(1):111-125. 